\title{
To analyse the demand pattern of consumptions of the premium ice creams in Metro cities in India w.r.t Amul's Crème Rich
}

\author{
Mrs. Roshni Sawant \\ D. Y. Patil School of Management /D Y Patil University, Mumbai India
}

\begin{abstract}
The objective of our research project is to focus \& study on Premium Ice Cream segment in India. The project is divided in three parts; Premium Ice cream segment with respect to Amul Rich cream premium ice cream, with respect to national competitors and with respect to international brands. To analyse the market by analysing consumer behaviour and retailers who sale ice cream of different brands. The ice cream market in India is estimated to be around INR 3,000 Crores, of which over 40\% belongs to the organized sector growing at about $15 \%$ Y-o-Y. Amul leads the pack with about 36-38\% market share (5\% of its total revenues), followed by Kwality Walls \&Vadilal with about 12-14\% share each. These players not only have to fight the small local and cottage industry players, but also the fact that the Indian cuisine itself offers a large variety of desserts which are still preferred by most Indians. Bulk of the sales happen during the summer months of April-July, while the sales witness a significant dip during winter months of November-February. Additionally, the seasonality of events like marriages affects sales in a big way, although institutional sales provide some cushion.
\end{abstract}

Keywords: Amul, Crème Rich, Magnum, Premium Ice Cream, Extrusion Bars.

\section{Introduction}

The objective of our research project is to focus \& study on Premium Ice Cream segment in India. The project is divided in three parts; Premium Ice cream segment with respect to Amul Rich cream premium ice cream, with respect to national competitors and with respect to international brands. To analyze the market by analyzing consumer behavior and retailers who sale ice cream of different brands.

The ice cream market in India is estimated to be around INR 3,000 Crores, of which over $40 \%$ belongs to the organized sector growing at about $15 \%$ Y-o-Y. Amul leads the pack with about 36-38\% market share (5\% of its total revenues), followed by Kwality Walls \&Vadilal with about $12-14 \%$ share each. These players not only have to fight the small local and cottage industry players, but also the fact that the Indian cuisine itself offers a large variety of desserts which are still preferred by most Indians. Bulk of the sales happen during the summer months of April-July, while the sales witness a significant dip during winter months of November-February. Additionally, the seasonality of events like marriages affects sales in a big way, although institutional sales provide some cushion. Once the ice cream melts, it is non-saleable, and drives retailers not to carry enough stocks - not an optimal situation given the not so favorable situation of cold chain in India.

With the latest mandate for HUL to increase its foods revenue, they might also be focusing on out-ofhome footprint through ice cream parlors, ice creams being a high growth category for HUL growing at about $31 \%$ last year. On one hand where Amul is trying to increase its reach by adding retail outlets to the tune of $15 \mathrm{k}$ to its base of 70k outlets, on the other hand HUL is focusing on new product launches and television campaigns for consumer activation. Half the market is driven by impulse purchase, and rest by family consumption at home and in-parlor sales. Grabbing this opportunity and After analyzing is market scenarios, Amul all set to storm the ice cream market with new Super Premium range of Ice cream "Amul Crème Rich" a boon to consumers who love to indulge in rich ingredients \&taste. Being the market leader in Ice cream segment Amul was not having any premium ice cream. There are niche players in the parlor business, with Nirula's being an established player in the north, and Naturals in the west; and then there are premium players like Baskin Robbins. Location is key here like in any retail business, to ensure enough footfalls and an optimal rental profile for sustained outlet level profitability. Brands are coming out with pro-biotic and low fat ice creams targeting the health conscious consumers, and also new manufacturing processes which reduce air content in ice creams giving more value for money to the consumers; but the acceptance for such products is still to be put to a proper test in the market.

Overall, the ice cream market is heating up. What is to be seen is that for whom this heat helps in increasing revenues \& profitability of players, or melts the aspirations in the sector."Premium" ice cream tends to have low overrun and higher fat content than regular ice cream, and the manufacturer uses higher quality ingredients. More overrun produces a fluffy, light ice cream with more air and less of everything else, including fat. Less overrun produces a creamy, dense ice cream with little air and a lot of fat. The lower the overrun, the creamier, smoother and richer the ice cream. But low overrun isn't all there is to super-premium ice cream. To 
earn this delicious seal of approval, ice cream has to contain at least $14 \%$ butterfat. This rich content of butterfat adds to the creamy, luscious texture and the full-bodied taste that super-premium treats are famous for.

Project objectives are divided into 3 parts-

\section{Headings}

-To study the premium ice cream segment in India with a view at Amul'sCrème Rich Ice cream

-To give recommendations for better retail penetration

-To do Comprehensive study on feasibility of extrusion bars

Primary Research Project:

-To study the premium ice cream segment in India.

-To study the marketing strategies of the premium Ice cream competitors.

-To study the customer's perception \& preferences for the premium Ice creams.

-To study the retailers preferences of the premium Ice creams.

-To study the preferences of those factors which are considerable by the Customer.

-To study the feasibility of Extrusion bar concept in premium Ice creams.

-To analyze the satisfaction level of the customers using factor analysis.

-To identify factors to focus for building of the Premium Ice cream "AmulCreme Rich".

\section{Research Methodology}

To achieve our research objective, we carried out our research $\&$ collected information $\&$ inputs from both Customers \& Retailers. For this project,

Sample size we chose is as follows:

- Customers - 100

- Retailers - 30

Location - ( Whole ) Mumbai

Analytical tools used - SPSS software, Excel Software

Primary data collection - Through questionnaire survey

Secondary data collection - Through online links \& articles

Tests applied - Frequency analysis, Factor analysis, Discriminant analysis, etc.

Customer's Analysis:

\section{Figures And Tables}

Test 1 - To determine Demographics ( Age\& Gender )

\begin{tabular}{|ll|r|r|r|r|}
\hline & & Gender & \multicolumn{1}{|c|}{ Valid Percent } & Cumulative Percent \\
\hline Valid & Male & 62 & 62.2 & 62.4 & 61.4 \\
& Female & 37 & 37.4 & 37.6 & 100.0 \\
& Total & 99 & 99.6 & 100.0 & \\
Missing & System & 1 & .4 & & \\
Total & & 100 & 100.0 & & \\
\hline
\end{tabular}
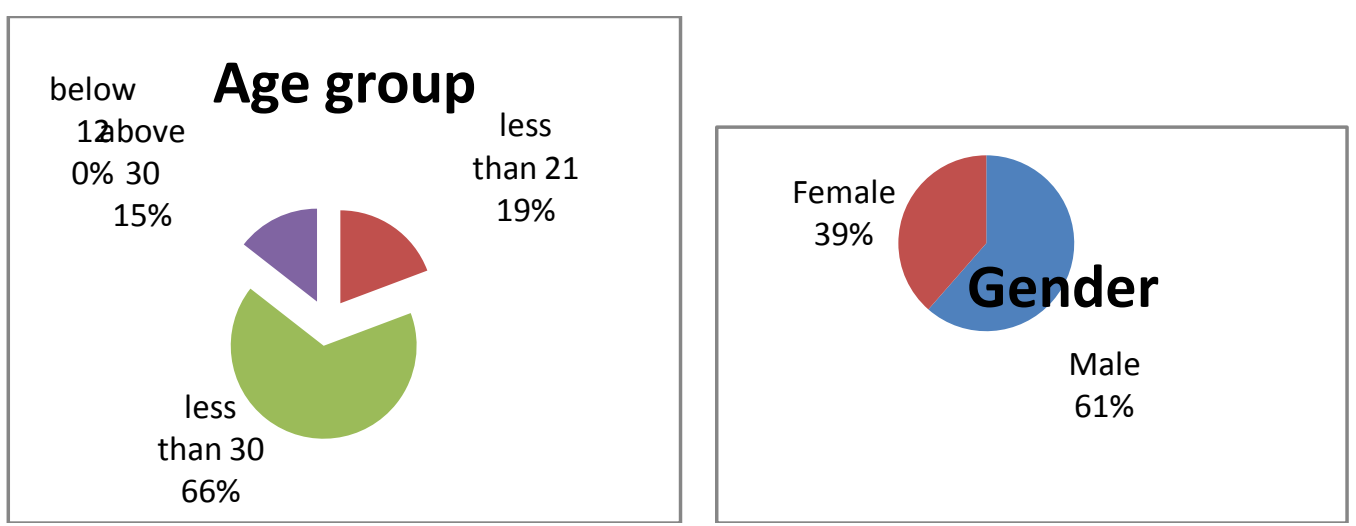


\begin{tabular}{|c|c|c|c|c|c|}
\hline \multicolumn{6}{|c|}{ Age } \\
\hline & & Frequency & Percent & Valid Percent & Cumulative Percent \\
\hline \multirow[t]{4}{*}{ Valid } & Less than 21 & 1 & 19.2 & 19.3 & 19.3 \\
\hline & Less than 30 & 6 & 66.0 & 66.3 & 85.5 \\
\hline & More than 30 & 1 & 14.4 & 14.5 & 100.0 \\
\hline & Total & 9 & 99.6 & 100.0 & \\
\hline Missing & System & & .4 & & \\
\hline Total & & 100 & 100.0 & & \\
\hline
\end{tabular}

Analysis \& Interpretation - From the frequency analysis, we can interpret that the number of males in sample size is $62 \&$ Females is 37. Most of the sample population falls into the age group of 21-30.

Hence we can conclude that results from the research might be tending more towards 21-30 age group perceptions.

Test 2 - To find out family size of sample population.

@4_No\#_of_Family_members_

\begin{tabular}{|ll|r|r|r|r|}
\hline & Frequency & Percent & Valid Percent & Cumulative Percent \\
\hline Valid & 4 & 31 & 30.8 & 38.9 & 38.9 \\
& 3 & 20 & 20.4 & 25.8 & 64.6 \\
& 5 & 15 & 15.6 & 19.7 & 84.3 \\
& 6 & 6 & 8.4 & 92.4 \\
& 2 & 3 & 3.4 & 3.0 & 95.5 \\
& 7 & 2 & 1.6 & 2.0 & 97.5 \\
& 8 & 2 & 1.2 & 1.5 & 99.0 \\
& 9 & 1 & .4 & .5 & 99.5 \\
& 10 & 1 & .4 & .5 & 100.0 \\
& Total & 81 & 79.2 & 100.0 & \\
Missing & System & 19 & 20.8 & & \\
Total & & 100 & 100.0 & & \\
\hline
\end{tabular}

Analysis \& Interpretation - From the frequency analysis, we can interpret that most of the families of sample population consist of 4 members, $3 \& 5$ being next bigger number of family size. So we can safely interpret that all the analysis we carry out from here on, will be most suitable for the family size of 3-5 Members.

Test 3- To find out most favorite premium Ice cream brand .

@_Which_is_your_most_favorite_Premium_Ice_cream_brand_

\begin{tabular}{|c|c|c|c|c|c|}
\hline & & Frequency & Percent & Valid Percent & Cumulative Percent \\
\hline \multirow[t]{11}{*}{ Valid } & Kw- Magnum & 33 & 33.6 & 33.6 & 33.6 \\
\hline & Gelato & 16 & 16.0 & 16.0 & 49.6 \\
\hline & Amul & 13 & 12.8 & 12.8 & 62.4 \\
\hline & Hagen Daz & 12 & 12.4 & 12.4 & 74.8 \\
\hline & Hockey Pockey & 10 & 10.4 & 10.4 & 85.2 \\
\hline & Havmor & 9 & 8.4 & 8.4 & 93.6 \\
\hline & London dairy & 4 & 3.6 & 3.6 & 97.2 \\
\hline & Others & 1 & 1.2 & 1.2 & 98.4 \\
\hline & Baskin Robins & 1 & .8 & .8 & 99.2 \\
\hline & Naturals & 1 & .8 & .8 & 100.0 \\
\hline & Total & 100 & 100.0 & 100.0 & \\
\hline
\end{tabular}




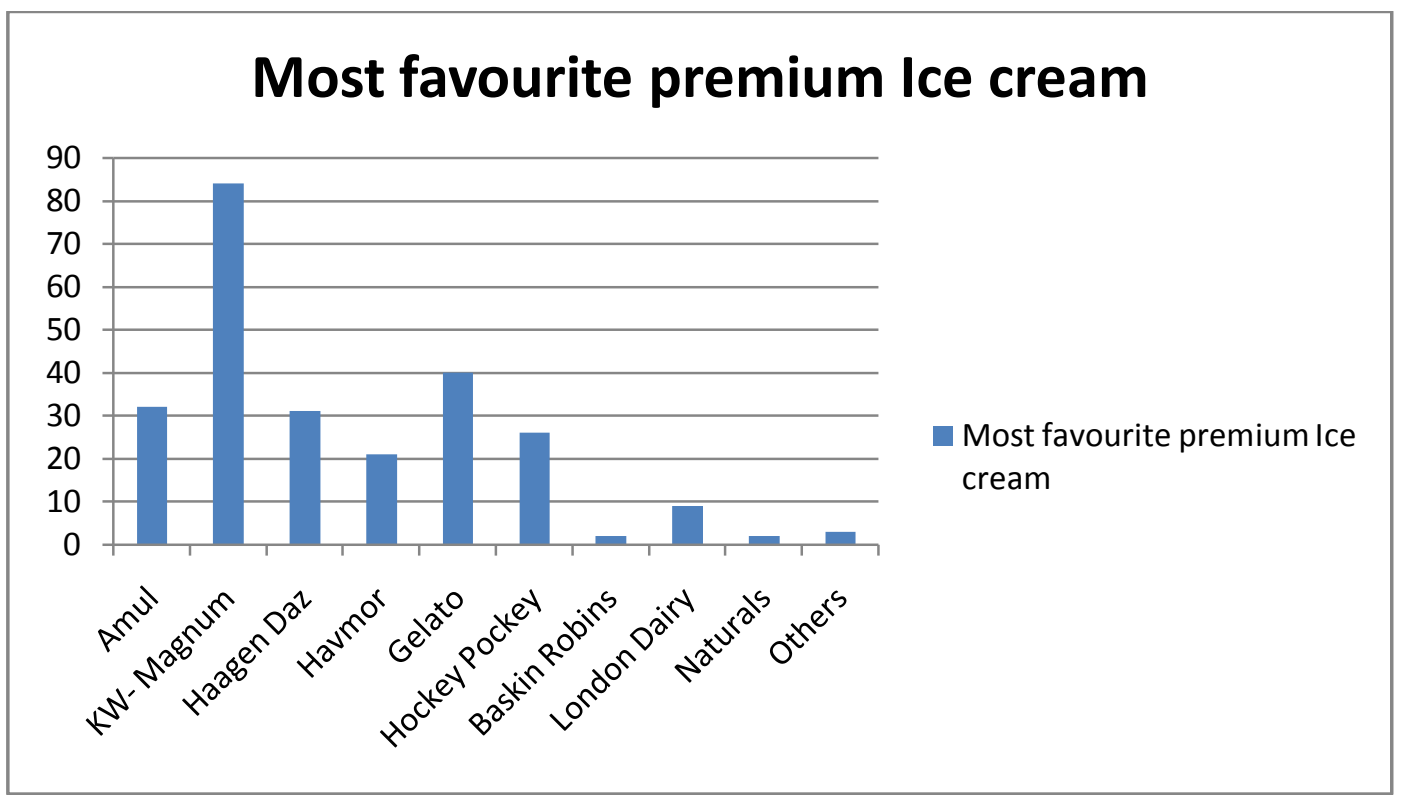

Analysis \& Interpretation - From the frequency analysis, we can interpret that KW-Magnum (33\%) is most favorite premium ice cream followed by Gelato \&Amul's Crème rich.

Test 4 - What makes people buy any particular brand of Ice Cream ?

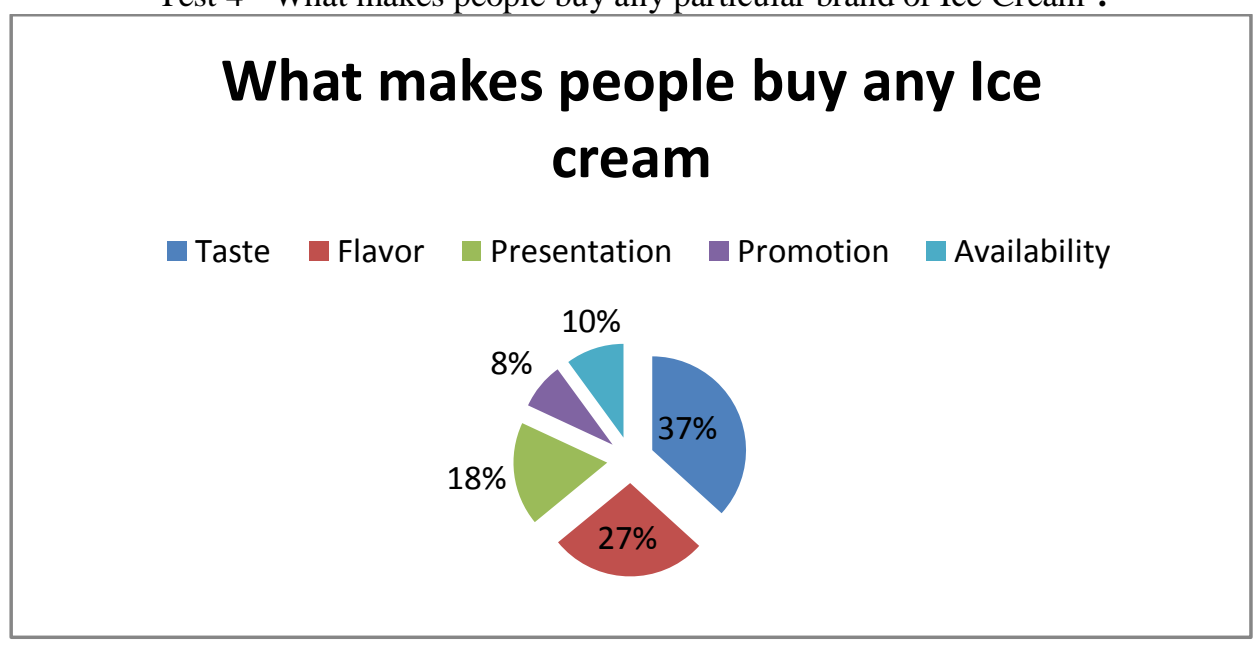

Analysis \& Interpretation - From the above pie chart, it's clear that the factors people consider most important while buying Ice cream are TASTE \& FLAVORS.

Test 5.1 - What is the current awareness scenario about Magnum Ice cream in people? @8_Are_you_aware_of_magnum_

\begin{tabular}{|ll|r|r|r|r|}
\hline & & Frequency & Percent & Valid Percent & Cumulative Percent \\
\hline Valid & Aware & 94 & 94.4 & 96.3 & 96.3 \\
& Not Aware & 6 & 3.6 & 3.7 & 100.0 \\
& Total & 100 & 98.0 & 100.0 & \\
Missing & System & 5 & 2.0 & & \\
Total & & 100 & 100.0 & & \\
\hline
\end{tabular}




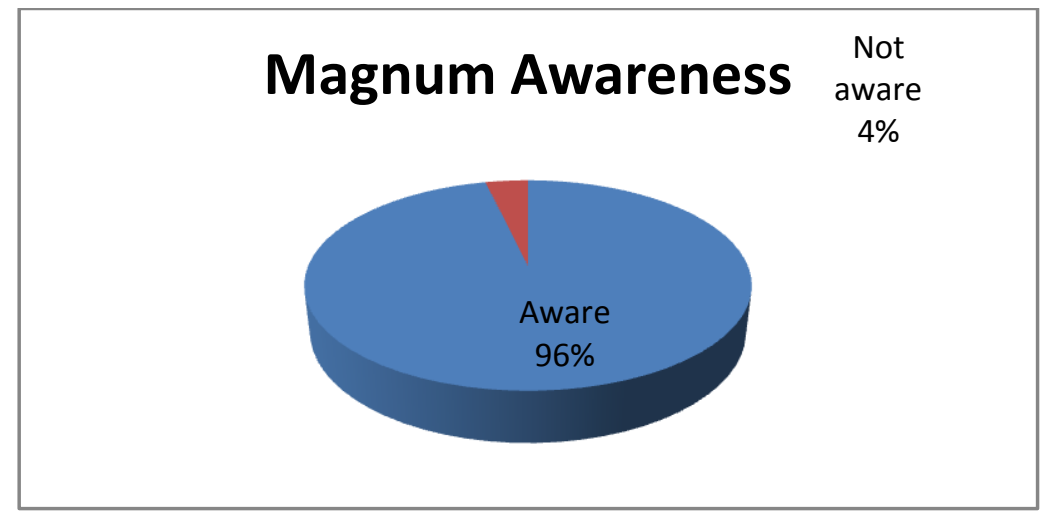

Analysis \& Interpretation -As much as $96 \%$ of total sample population is aware of Magnum which indicates that magnum awareness among people is very strong .

Test 5.2-To see if there's any impact or relation between Brand ambassador \& high awareness of magnum

Hypothesis - To check If there's any impact-relation between brand ambassador \& magnum awareness.

\begin{tabular}{|c|c|c|c|c|c|c|}
\hline \multicolumn{7}{|c|}{ Case Processing Summary } \\
\hline & \multicolumn{6}{|c|}{ Cases } \\
\hline & \multicolumn{2}{|c|}{ Valid } & \multicolumn{2}{|c|}{ Missing } & \multicolumn{2}{|c|}{ Total } \\
\hline & $\mathrm{N}$ & Percent & $\mathrm{N}$ & Percent & $\mathrm{N}$ & Percent \\
\hline $\begin{array}{l}@ 8 \text { @Are_you_aware_of_magnum_ } \\
-{ }^{*} \\
\text { @8\#7Are_you_aware_of_Brand_a } \\
\text { mbassador_of_Magnum_ }\end{array}$ & 9 & $94.4 \%$ & 14 & $5.6 \%$ & 250 & $100.0 \%$ \\
\hline
\end{tabular}

\begin{tabular}{|c|c|c|c|c|c|}
\hline & Value & Df & $\begin{array}{l}\text { Asymp. Sig. (2- } \\
\text { sided) }\end{array}$ & Exact Sig. (2-sided) & Exact Sig. (1-sided) \\
\hline Pearson Chi-Square & $9.416^{\mathrm{a}}$ & 1 & .002 & \multirow{6}{*}{.005} & \multirow{6}{*}{.005} \\
\hline Continuity Correction ${ }^{\mathrm{b}}$ & 6.735 & 1 & .009 & & \\
\hline Likelihood Ratio & 10.651 & 1 & .001 & & \\
\hline Fisher's Exact Test & & & & & \\
\hline Linear-by-Linear Association & 9.376 & 1 & .002 & & \\
\hline $\mathrm{N}$ of Valid Cases ${ }^{\mathrm{b}}$ & 86 & & & & \\
\hline
\end{tabular}

a. 2 cells $(50.0 \%)$ have expected count less than 5 . The minimum expected count is 1.76 .

b. Computed only for a $2 \times 2$ table

Analysis \& Interpretation - From our cross tab - Pearson chi square test , $\mathrm{p}=.002$ which is less than .05 This indicates that there is significant impact of Brand ambassador on magnum awareness. This indicates that the brand ambassador campaign for Magnum carried out by Kwality Walls is one of the important parameter in huge popularity of Magnum.

Test 5.3 - Magnum Most favoriteflavor @8\#5__Which_flavor_do_you_prefer_in_Magnum_

\begin{tabular}{|ll|r|r|r|r|}
\hline & & Frequency & Percent & Valid Percent & Cumulative Percent \\
\hline Valid & Chocolate truffle & 60 & 59.6 & 61.6 & 61.6 \\
& Almond & 24 & 23.6 & 24.4 & 86.0 \\
& Classic & 14 & 13.6 & 14.0 & 100.0 \\
& Total & 98 & 96.8 & 100.0 & \\
Missing & System & 2 & 3.2 & & \\
Total & & 100 & 100.0 & & \\
\hline
\end{tabular}




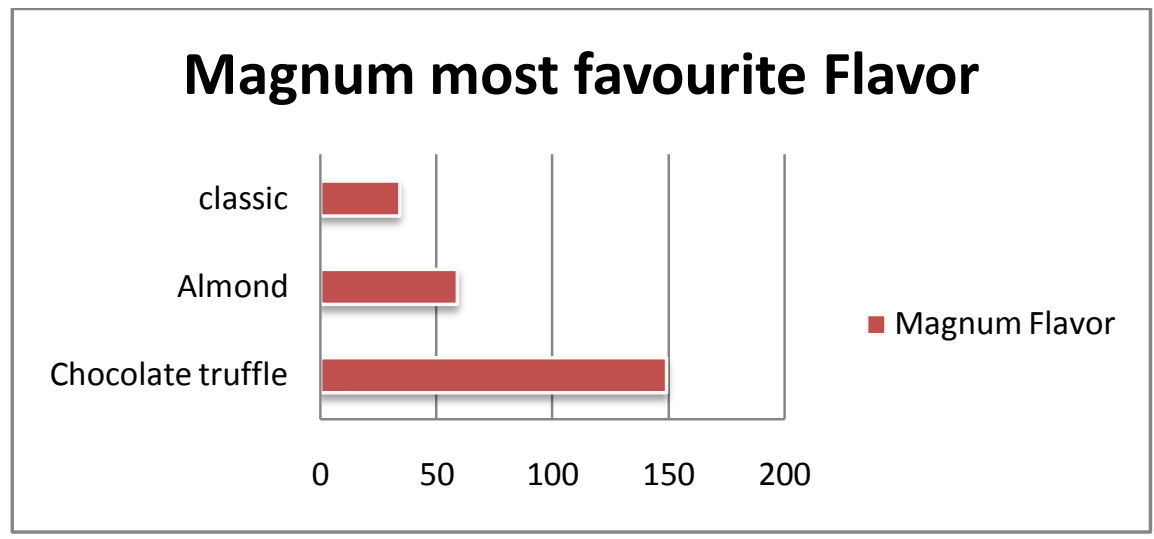

Analysis \& Interpretation - From the frequency analysis of the input data for most favoriteflavor of magnum among people, we came to know that more than $60 \%$ of customers prefer chocolate truffle flavor of Magnum where as almond \& classic have moderate to low demand.

Test 5.4 - To check Brand ambassador awareness

@8\#7Are_you_aware_of_Brand_ambassador_of_Magnum_

\begin{tabular}{|ll|r|r|r|r|}
\hline & & Frequency & Percent & Valid Percent & Cumulative Percent \\
\hline Valid & Yes & 63 & 63.2 & 65.6 & 65.6 \\
& No & 33 & 33.2 & 34.4 & 100.0 \\
& Total & 96 & 96.4 & 100.0 & \\
Missing & System & 4 & 3.6 & & \\
Total & & 100 & 100.0 & & \\
\hline
\end{tabular}

\section{Brand ambassdor awareness}

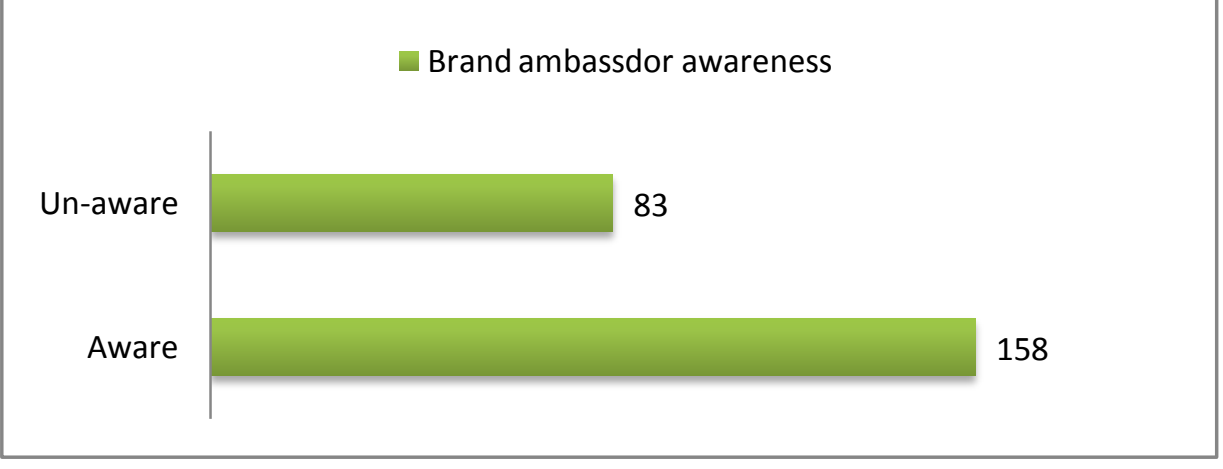

Analysis \& Interpretation - From the frequency analysis of the collected input data, we can interpret that $65 \%$ customers are aware of brand ambassador of Magnum where as 35\% of the customers either don't know or have forgotten about her (Kareena Kapoor ) .

Test 6 - Factor Analysis ( To find out Factors affecting customers buying decision )

To initially test if the sample size we selected is good enough to carry out factor analysis \& if yes, then to find out factors which needs more attention i.e. more improvement can be done in those factors $\&$ to find out factors which are performing at satisfactory level.

\begin{tabular}{|c|c|c|}
\hline \multicolumn{3}{|c|}{ KMO and Bartlett's Test } \\
\hline \multicolumn{2}{|c|}{ Kaiser-Meyer-Olkin Measure of Sampling Adequacy. } & .873 \\
\hline Bartlett's Test of Sphericity & Approx. Chi-Square & 975.60 \\
\hline & Df & 62 \\
\hline & Sig. & .001 \\
\hline
\end{tabular}

Total Variance Explained 


\begin{tabular}{|c|c|c|c|c|c|c|c|c|c|}
\hline \multirow[b]{2}{*}{ Component } & \multicolumn{3}{|c|}{ Initial Eigenvalues } & \multicolumn{3}{|c|}{ Extraction Sums of Squared Loadings } & \multicolumn{3}{|c|}{ Rotation Sums of Squared Loadings } \\
\hline & Total & $\begin{array}{c}\% \text { of } \\
\text { Variance }\end{array}$ & Cumulative $\%$ & Total & $\begin{array}{c}\% \text { of } \\
\text { Variance }\end{array}$ & $\begin{array}{c}\text { Cumulative } \\
\%\end{array}$ & Total & $\begin{array}{c}\% \text { of } \\
\text { Variance }\end{array}$ & $\begin{array}{c}\text { Cumulative } \\
\%\end{array}$ \\
\hline 1 & 5.924 & 49.367 & 49.367 & 5.924 & 49.367 & 49.367 & 4.417 & 36.807 & 36.807 \\
\hline 2 & 2.116 & 17.629 & 66.996 & 2.116 & 17.629 & 66.996 & 2.317 & 19.305 & 56.112 \\
\hline 3 & .833 & 6.946 & 73.942 & .833 & 6.946 & 73.942 & 2.140 & 17.830 & 73.942 \\
\hline 4 & .709 & 5.912 & 79.854 & & & & & & \\
\hline 5 & .553 & 4.608 & 84.463 & & & & & & \\
\hline 6 & .447 & 3.721 & 88.184 & & & & & & \\
\hline 7 & .368 & 3.069 & 91.253 & & & & & & \\
\hline 8 & .283 & 2.358 & 93.611 & & & & & & \\
\hline 9 & .240 & 1.998 & 95.610 & & & & & & \\
\hline 10 & .231 & 1.922 & 97.531 & & & & & & \\
\hline 11 & .172 & 1.436 & 98.968 & & & & & & \\
\hline 12 & .124 & 1.032 & 100.000 & & & & & & \\
\hline
\end{tabular}

Extraction Method: Principal Component

Analysis.

Rotated Component Matrix ${ }^{\mathrm{a}}$

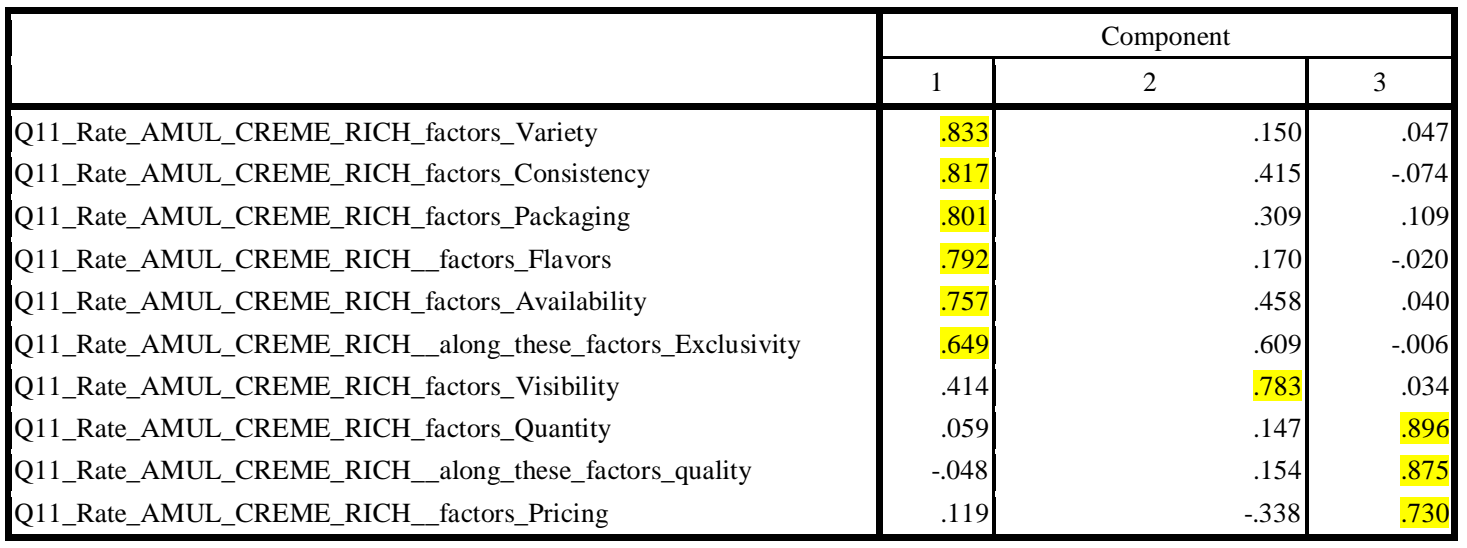

Analysis \& Interpretation- The analysis is done for 100 consumers.

In the above KMO Table, $\mathrm{P}$ Value is 0.001 which means $\mathrm{P}$ Value $<0.05$ This shows that the above parameters are highly significant. Sampling adequacy should be more than 0.5 to perform factor analysis. The above table shows a sampling adequacy of 0.873 which means factor analysis can be performed.The 3 factors that we have extracted from above 10 parameters (items) are able to explain $74 \%$ of variation.

$1^{\text {st }}$ Factor explains about the quality VARIERTY, CONSISTENCY, EXCLUSIVITY , PACKAGING, FLAVORS \& AVAILABILITY provided by Amul.

From the table values, we can interpret that factor 1 needs more attention from Amul since there is plenty of room for improvement since customers have rated most of the parameters in this factor as negative.

$2^{\text {nd }}$ Factor includes the VISIBILITY

From the table, we can interpret that factor 2 needs moderate level of attention from Amul as customers are moderately satisfactory about parameters defining factor 2 .

3rd Factor includes QUALITY, QUANTITY\& PRICING .

From the table values, we can interpret that customers are quite satisfied about the parameters making Factor 3 $\&$ hence factor 3 needs least part of attention compared to other 2 factors. 
Test 7 - DISRCRIMINANT ANALYSIS

\begin{tabular}{|l|l|}
\hline & Function \\
\hline @9_How_would_you_Rate_AMUL_CREME_RICH_along_these_factors_QUALITY & 1 \\
@9_How_would_you_Rate_AMUL_CREME_RICH__along_these_factors_QUANTITY & .971 \\
@9_How_would_you_Rate_AMUL_CREME_RICH__along_these_factors_PRICING & -.469 \\
@9_How_would_you_Rate_AMUL_CREME_RICH__along_these_factors_ADVERTISING & .347 \\
@9_How_would_you_Rate_AMUL_CREME_RICH__along_these_factors_PACKAGING & .325 \\
@9_How_would_you_Rate_AMUL_CREME_RICH__along_these_factors_FLAVORS & -.030 \\
@9_How_would_you_Rate_AMUL_CREME_RICH__along_these_factors_AVAILABILITY & .453 \\
@9_How_would_you_Rate_AMUL_CREME_RICH__along_these_factors_CONSISTENCY & -.334 \\
@9_How_would_you_Rate_AMUL_CREME_RICH__along_these_factors_VISIBILITY & .096 \\
@9_How_would_you_Rate_AMUL_CREME_RICH__along_these_factors_VARIETY & -.255 \\
(Constant) & .413 \\
\hline
\end{tabular}

Functions at Group Centroids

\begin{tabular}{|l|l|}
\hline \multirow{2}{*}{ @5_Are_you_aware_of_Amul_Premium_Ice_cream_ } & Function \\
\cline { 2 - 2 } & 1 \\
\hline YES & .048 \\
\hline
\end{tabular}

Classification Results ${ }^{\mathrm{a}}$

\begin{tabular}{|c|c|c|c|c|c|}
\hline & & \multirow[b]{2}{*}{ @5_Are_you_aware_of_Amul_Premium_Ice_cream } & \multicolumn{2}{|c|}{ Predicted Group Membership } & \multirow[b]{2}{*}{ Total } \\
\hline & & & YES & NO & \\
\hline \multirow[t]{6}{*}{ Original } & Count & YES & 164 & 0 & 164 \\
\hline & & NO & 11 & 0 & 11 \\
\hline & & Ungrouped cases & 1 & 0 & 1 \\
\hline & $\%$ & YES & 100.0 & .0 & 100.0 \\
\hline & & NO & 100.0 & .0 & 100.0 \\
\hline & & Ungrouped cases & 100.0 & .0 & 100.0 \\
\hline
\end{tabular}

a. $93.7 \%$ of original grouped cases correctly classified.

Interpretation \& Analysis - The analysis is done for 100 consumers.

We have performed Discriminant Analysis taking 10 factors into consideration.

This table is possible taking 1 dependent function and various independent functions.

From the above table, the equation performed is such:

Discriminant analysis - Discriminant Model

$\mathrm{Y}=\quad-.115+.413$ Variety- 0.255 Visibility +0.96 Consistency- 0.334 availability +.0453 Flavors0.30 Packaging+0.325Advertising+0.347Pricing-0.469Quantity +0.971 Quality

$\mathrm{Y}=1.996$

As our calculated value 1.996 is more closer to value .48 , we can interpret that most of all the customers who are aware of Amulcreme Rich will purchase it at any given situation .

Test 8 - To find out customers willingness to spend on the Premium Ice creams per visit @How_much_are_you_willing_to_spend_on_Premium_Ice_creams_

\begin{tabular}{|ll|l|l|l|l|}
\hline \multicolumn{1}{|c|}{} & Frequency & Percent & Valid Percent & Cumulative Percent \\
\hline Valid & Less than 100 & 16 & 16.8 & 16.9 & 16.9 \\
& Less than 250 & 56 & 55.6 & 56.0 & 73.0 \\
Less than 500 & 24 & 24.8 & 25.0 & 98.0 \\
More than 500 & 4 & 2.0 & 2.0 & 100.0 \\
Missing & Total & 98 & 99.2 & 100.0 & \\
\hline
\end{tabular}


@How_much_are_you_willing_to_spend_on_Premium_Ice_creams_

\begin{tabular}{|ll|l|l|l|l|}
\hline & & Frequency & Percent & Valid Percent & Cumulative Percent \\
\hline Valid & Less than 100 & 16 & 16.8 & 16.9 & 16.9 \\
& Less than 250 & 56 & 55.6 & 56.0 & 73.0 \\
& Less than 500 & 24 & 24.8 & 25.0 & 98.0 \\
& More than 500 & 4 & 2.0 & 2.0 & 100.0 \\
& Total & 98 & 99.2 & 100.0 & \\
Missing & System & 2 & .8 & & \\
Total & & 100 & 100.0 & & \\
\hline
\end{tabular}

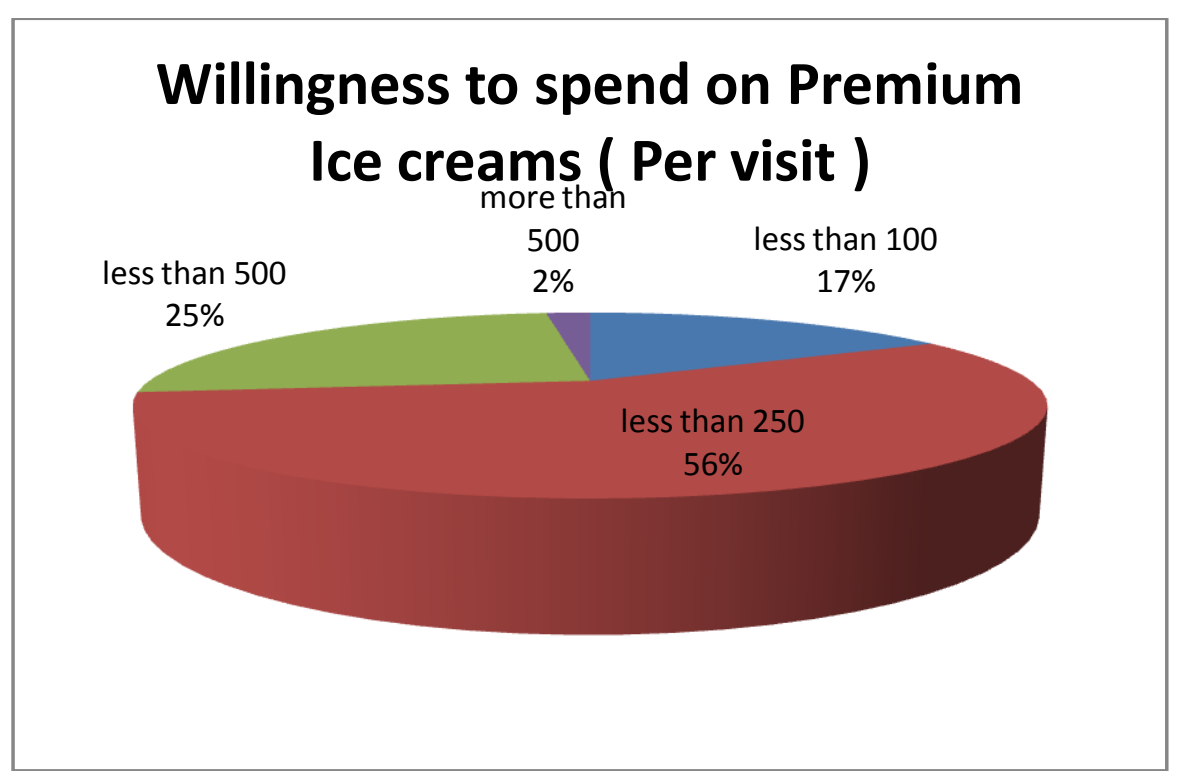

Analysis \& Interpretation - From the above frequency analysis, we can interpret that more than $50 \%$ of customers are willing to spend amount somewhere between Rs.100 to Rs. 250 .

Around $25 \%$ of customers are willing to spend up to Rs.500.

Around $17 \%$ of customers are willing to spend up to Rs.100

Very less number of customers arewilling to spend more than Rs.500

Test 9 - How customers prefer their premium ice creams to be served?

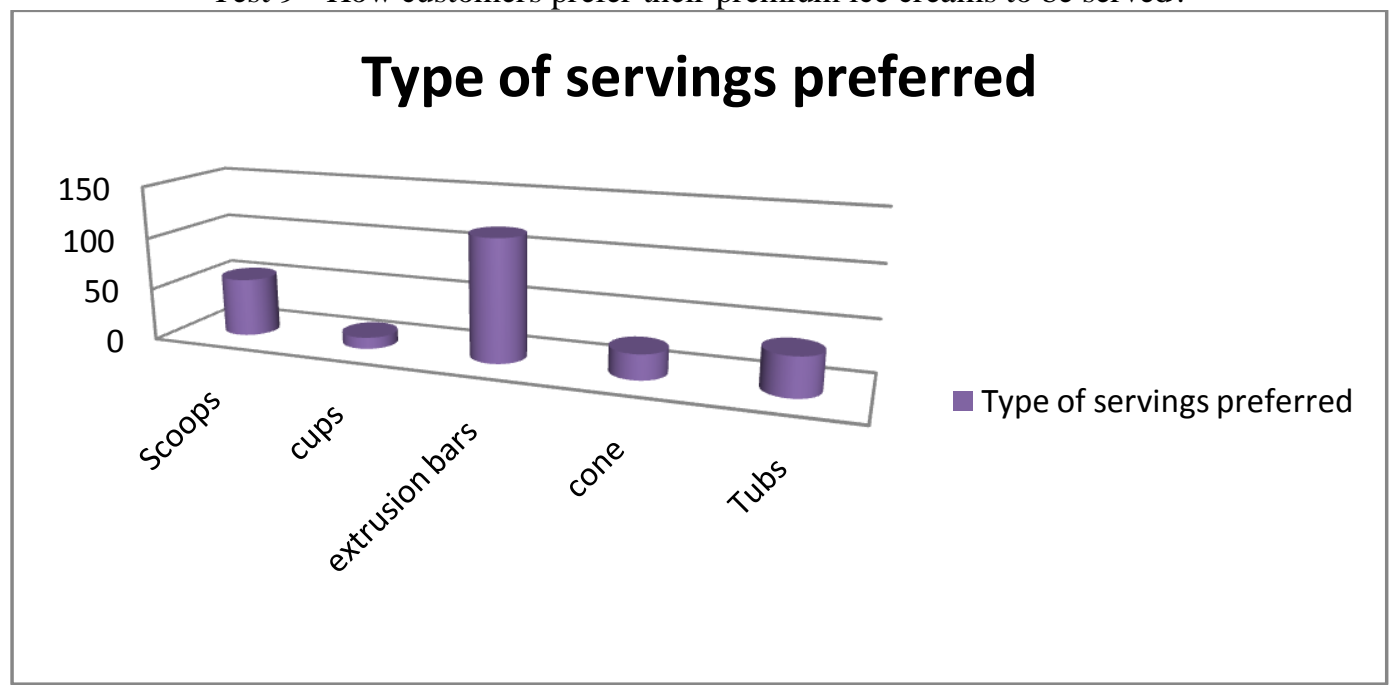

Analysis \& Interpretation - From the frequency analysis of the collected data, we can interpret that most of the customers prefer Premium Ice cream in Extrusion bar serving type ( Mostly because of Magnum )

It can be also seen in the chart that scoops is second most preferred type of servings after extrusion bars which means that customers also like to have their premium ice cream in scoop servings. 
It's interesting to know that customers chose cups to be their least preferred type of serving when it comes to premium Ice creams where as tubs $\&$ cones both have moderate demand among customers.

Test 10 - Will customers buy Amul crème rich if it comes in Extrusion bar serving type?

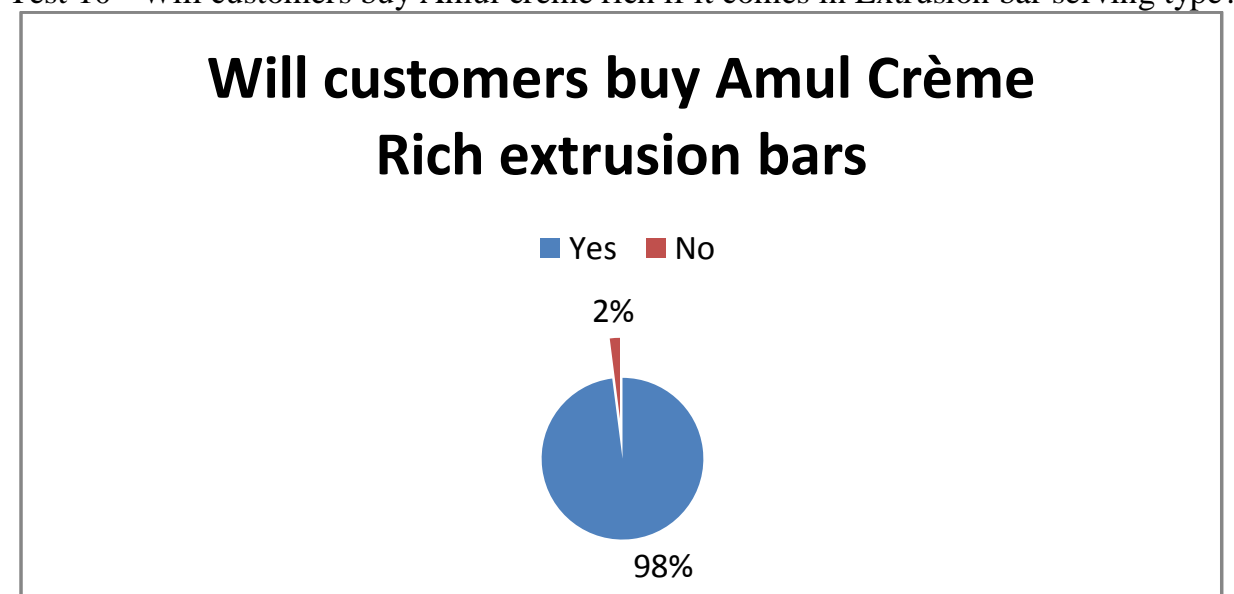

Analysis \& Interpretation - From the frequency analysis, we can say that almost $98 \%$ of the customers are willing to buy Amul crème rich if it comes in Extrusion bar format.

Retailer's Analysis:

Test 1 - To check what \% of retailers keep stock of Premium Ice cream? Q1__Do_you_keep_stock_of_Premium_Ice_creams_

\begin{tabular}{|ll|l|l|l|l|}
\hline & Frequency & Percent & Valid Percent & Cumulative Percent \\
\hline Valid & Yes & 27 & 90.7 & 90.7 & 90.7 \\
& No & 3 & 9.3 & 9.3 & 100.0 \\
& Total & 30 & 100.0 & 100.0 & \\
\hline
\end{tabular}

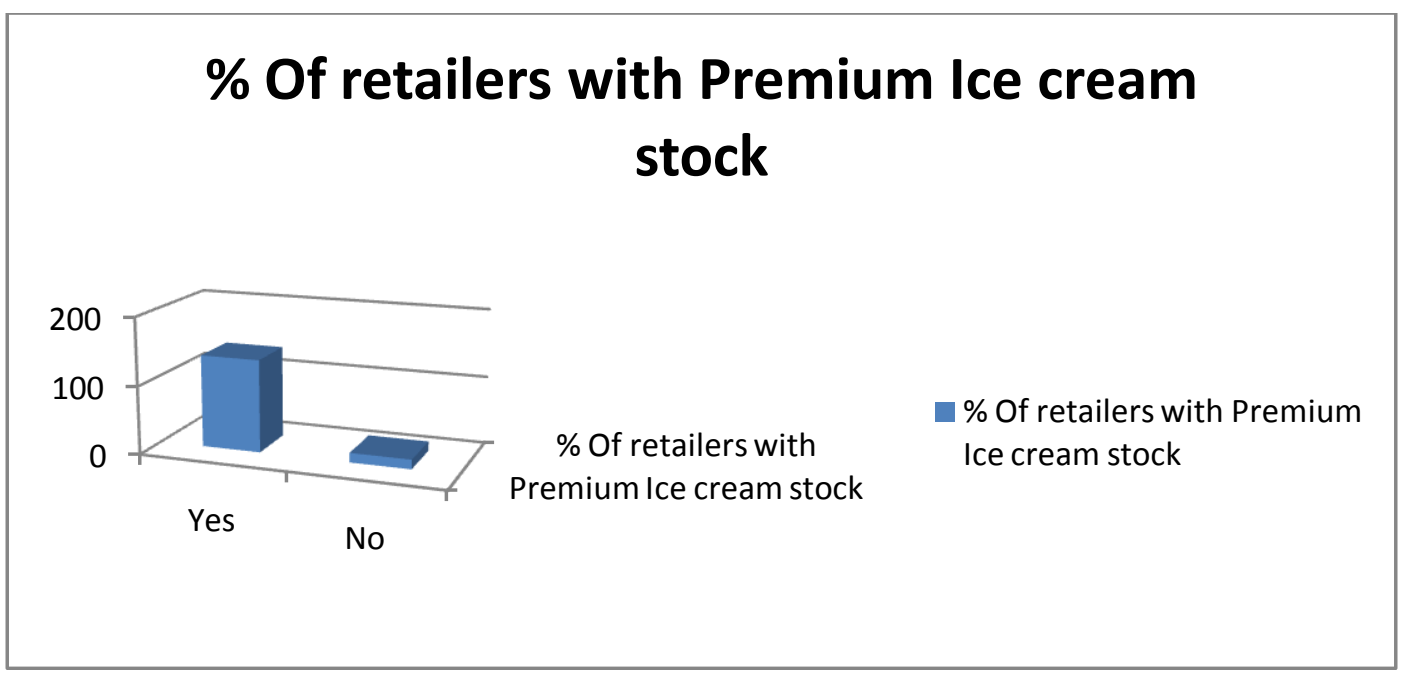

Analysis \& Interpretation - From freq. analysis ,we can interpret that most of the retailers (above 90\%) do keep stock of premium Ice cream.Most of these stores being retailers,$\&$ since there are very few premium ice cream market players who sell premium ice creams through Retailers, we can strongly conclude that Magnum \&havmor have good retail penetration \& will be biggest competitors in terms of retail penetration challenge. 
Test 2 - To check current penetration level of AmulCreme Rich Q8_Are_you_currently_stocking_Amul_Creme_Rich_

\begin{tabular}{|ll|l|l|l|l|}
\hline & Frequency & Percent & Valid Percent & Cumulative Percent \\
\hline Valid & YES & 25 & 83.3 & 83.3 & 83.3 \\
& NO & 5 & 16.7 & 16.7 & 100.0 \\
& Total & 30 & 100.0 & 100.0 & \\
\hline
\end{tabular}

\section{Amul crème Rich retail penetration}

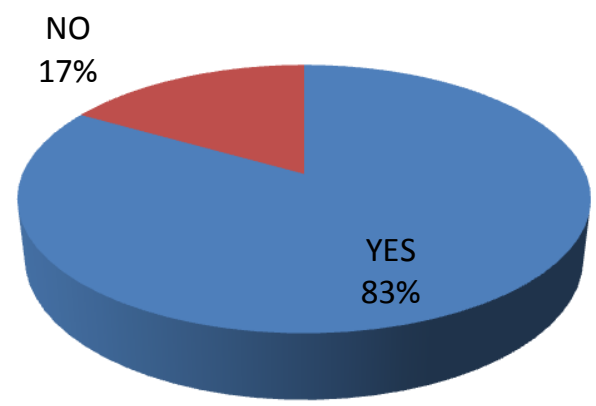

Analysis \& Interpretation - From above frequency analysis, we can interpret that Amulcreme rich has achieved $83 \%$ retail penetration in the retail market with only $17 \%$ of market left to be penetrated.

Test 3 - Most popular flavor in the Amul's Crème Rich Q10_Which_flavors_have_higher_demand_

\begin{tabular}{|ll|l|l|l|l|}
\hline & & Frequency & Percent & Valid Percent & Cumulative Percent \\
\hline Valid & Almond fudge & 16 & 44.0 & 55.0 & 55.0 \\
& Caramel & 8 & 22.7 & 28.3 & 83.3 \\
& Vanilla & 6 & 13.3 & 16.7 & 100.0 \\
& Total & 30 & 80.0 & 100.0 & \\
Missing & System & 00 & 20.0 & & \\
Total & & 30 & 100.0 & & \\
\hline
\end{tabular}

Analysis \& Interpretation - From the frequency analysis, we can interpret that Almond Fudge is currently most preferred flavor by the customers caramel being the second most preferred \&vanilla third preferred flavor.

Test 4- To check if all those retailers who stock premium ice creams also stock Amulcreme rich ? _Do_you_keep_stock_of_Premium_Ice_creams_* Q8_Are_you_currently_stocking_Amul_Creme_Rich_Crosstabulation

\begin{tabular}{|c|c|c|c|c|}
\hline & & \multicolumn{2}{|c|}{$\begin{array}{l}\text { Q8_Are_you_currently_stocking_Amu } \\
\text { 1_Creme_Rich_ }\end{array}$} & \multirow[b]{2}{*}{ Total } \\
\hline & & Yes & No & \\
\hline \multirow{4}{*}{$\begin{array}{l}\text { Q5_Do_you_keep_stock_of_Pr (No) } \\
\text { emium_Ice_creams_ }\end{array}$} & Count & 1 & 13 & 14 \\
\hline & $\begin{array}{l}\% \\
\text { Q5__Do_you_keep_stock_of_Pr } \\
\text { emium_Ice_creams__ }\end{array}$ & $7.1 \%$ & $92.9 \%$ & $100.0 \%$ \\
\hline & Count & 124 & 12 & 136 \\
\hline & $\begin{array}{l}\% \\
\text { Q5__Do_you_keep_stock_of_Pr } \\
\text { emium_Ice_creams_ }\end{array}$ & $91.2 \%$ & $8.8 \%$ & $100.0 \%$ \\
\hline \multirow[t]{2}{*}{ Total } & Count & 125 & 25 & 150 \\
\hline & $\begin{array}{l}\% \\
\text { Q5__Do_you_keep_stock_of_Pr } \\
\text { emium_Ice_creams_ }\end{array}$ & $83.3 \%$ & $16.7 \%$ & $100.0 \%$ \\
\hline
\end{tabular}


Chi-Square Tests

\begin{tabular}{|l|l|l|l|l|l|}
\hline & Value & df & $\begin{array}{l}\text { Asymp. Sig. (2- } \\
\text { sided) }\end{array}$ & Exact Sig. (2-sided) & Exact Sig. (1-sided) \\
\hline Pearson Chi-Square & $64.538^{\mathrm{a}}$ & 1 & .000 & & \\
Continuity Correction ${ }^{\mathrm{b}}$ & 58.629 & 1 & .000 & .000 & .000 \\
Likelihood Ratio & 46.789 & 1 & & .000 & \\
Fisher's Exact Test & 64.108 & 1 & & & \\
Linear-by-Linear Association & 150 & & & & \\
N of Valid Cases & & & & \\
\hline
\end{tabular}

a. 1 cells $(25.0 \%)$ have expected count less than 5 . The minimum expected count is 2.33 .

b. Computed only for a $2 \times 2$ table

Analysis \& Interpretation - From above Chi square test analysis, we can interpret that most of the retailers who stock premium Ice creams also have started to stock Amul's Crème Rich ( $91 \%$ ). Also, there are still $8 \%$ of the retailers, who do stock premium ice creams but are yet to start with Amul'sCrème Rich ice cream.

Test 5- To see the response so far for AmulCreme Rich

Q8\#1_If_yes_how_is_the_response_to_it_

\begin{tabular}{|ll|l|l|l|l|}
\hline & & Frequency & Percent & Valid Percent & Cumulative Percent \\
\hline Valid & Good & 10 & 34.7 & 41.3 & 41.3 \\
& Fair & 6 & 20.7 & 24.6 & 65.9 \\
& Not Much & 4 & 12.0 & 14.3 & 80.2 \\
& Very Good & 3 & 10.0 & 11.9 & 92.1 \\
& Poor & 2 & 6.7 & 7.9 & 100.0 \\
& Total & 30 & 84.0 & 100.0 & \\
Missing & System & 5 & 16.0 & & \\
Total & & 30 & 100.0 & & \\
\hline
\end{tabular}

\section{Amul Crème Rich Response}

$\square$ very good $\square$ good $\square$ fair $\square$ not much $\square$ poor

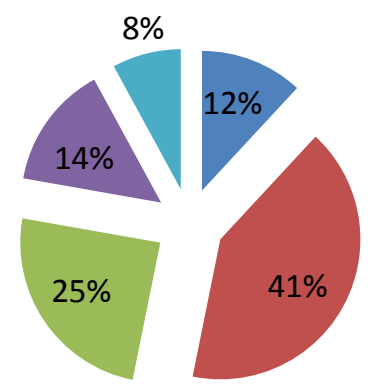

Analysis \& Interpretation- From the frequency analysis, we can interpret that most part of response ranges between very good to fair ( up to $41+25+12=78 \%$ ), "GOOD" being the much higher response till now. Very few shop owners have responded that AmulCreme rich is performing Poorly. 
Test 6 - To identify most preferred packing in premium ice creams Q14_Which_type_of_Packing_customers_prefer_in_Premium_Ice_cream

\begin{tabular}{|ll|l|l|l|l|}
\hline & & Frequency & Percent & Valid Percent & Cumulative Percent \\
\hline Valid & Extrusion bars & 21 & 69.3 & 71.2 & 71.2 \\
& Cones & 4 & 14.7 & 15.1 & 86.3 \\
& Tubs & 3 & 10.7 & 11.0 & 97.3 \\
& Cups & 1 & 2.7 & 2.7 & 100.0 \\
& Total & 29 & 97.3 & 100.0 & \\
Missing & System & 1 & 2.7 & & \\
Total & & 30 & 100.0 & & \\
\hline
\end{tabular}

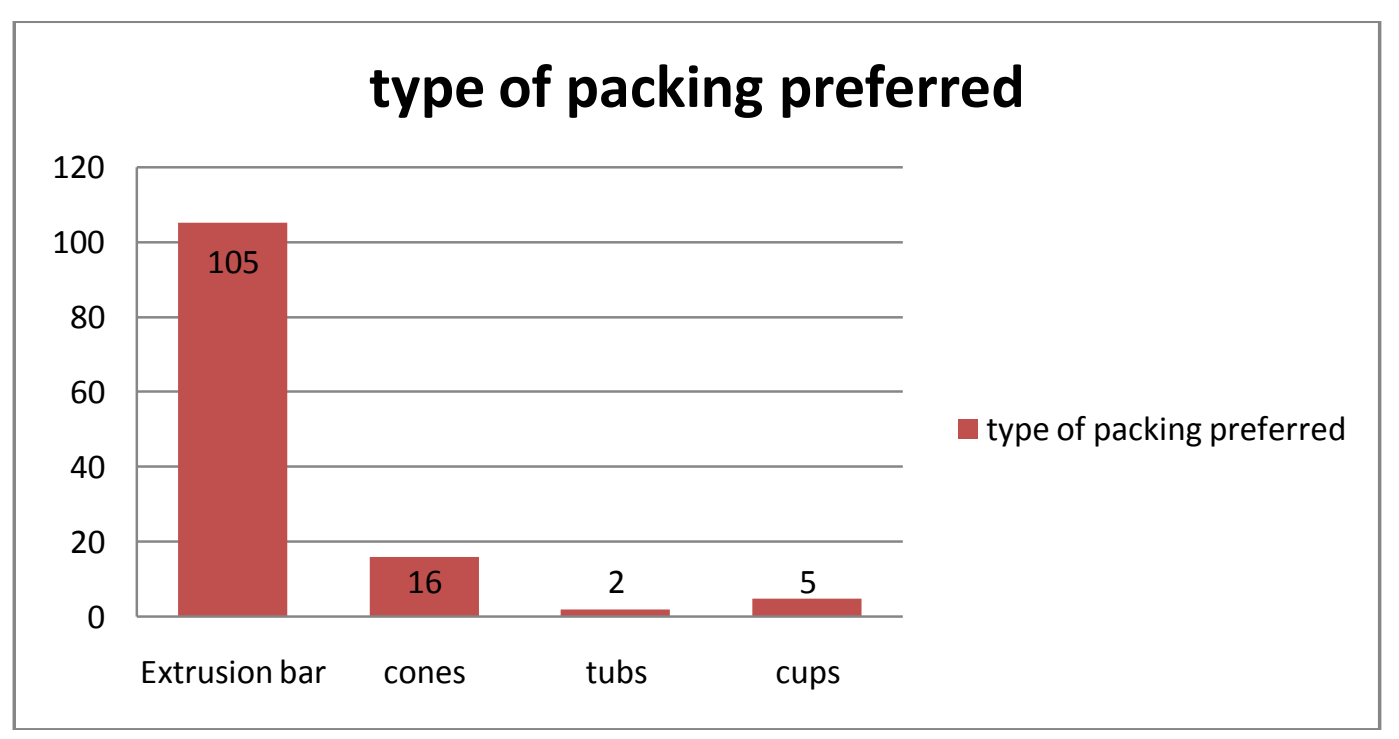

Analysis \& Interpretation - We can see that there is huge demand for Extrusion bars when it comes to Premium Ice cream sales from Retail stores( Current Major players - Magnum, Havmor ).Cones, cups \& Tubs have very low demand compared to extrusion Bar format of packaging.

Test 7.1 - To check Magnum penetration in the retail market Q18_Do_you_Stock_Magnum_

\begin{tabular}{|ll|l|l|l|l|}
\hline & & Frequency & Percent & Valid Percent & Cumulative Percent \\
\hline Valid & YES & 19 & 62.0 & 62.0 & 62.0 \\
& NO & 11 & 38.0 & 38.0 & 100.0 \\
& Total & 30 & 100.0 & 100.0 & \\
\hline
\end{tabular}

\begin{tabular}{|l|}
\hline Magnum retail penetration \\
$\qquad$ Yes $\square$ No \\
$38 \%$ \\
$62 \%$ \\
\hline
\end{tabular}


Analysis \& Interpretation - From the frequency analysis, we can interpret that Magnum market penetration is about $62 \%$.

Test 7.2 - To check response for Magnum to the retailers

Q_18\#2_How_is_the_response_for_Magnum_

\begin{tabular}{|ll|l|l|l|l|}
\hline & & Frequency & Percent & Valid Percent & Cumulative Percent \\
\hline Valid & Very good & 15 & 46.7 & 77.8 & 77.8 \\
& Ok & 4 & 13.3 & 22.2 & 100.0 \\
& Total & 19 & 60.0 & 100.0 & \\
Missing & System & 11 & 40.0 & & \\
Total & & 30 & 100.0 & & \\
\hline
\end{tabular}

Analysis \& Interpretation - From frequency analysis of inputs, we can interpret that Magnum has received very good response from customers (77\% Of the total retail stores who keep Magnum) whereas 22\% retailers got Ok response from customers.Interesting thing to notice is that, there are no POOR responses received by any retailer who sells Magnum.

Test 7.3 Why do retailers stock Magnum?

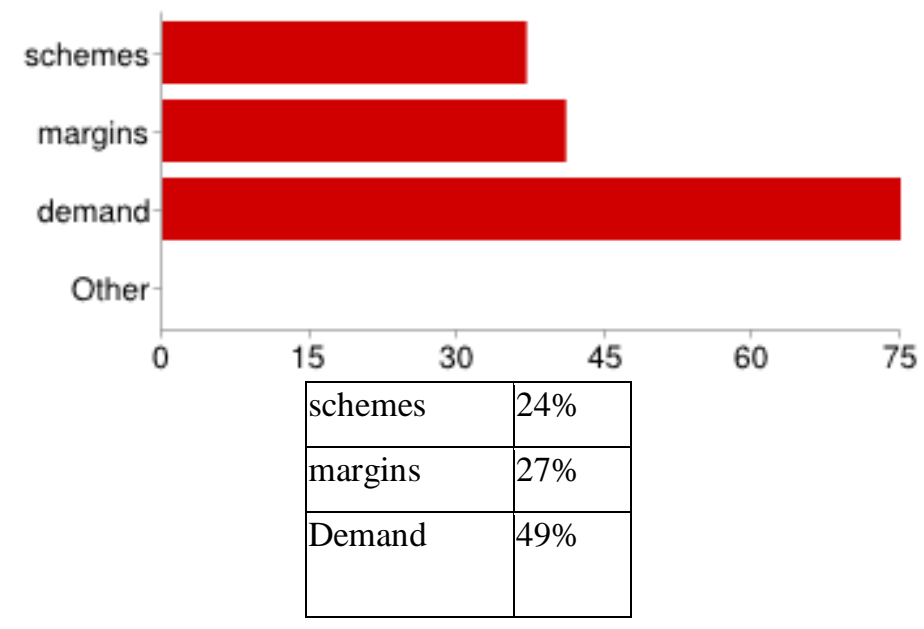

Interpretation \& Analysis - From frequency analysis, we can interpret that retailers primarily stock magnum because there is huge demand for it. Whereas retailers rated schemes \& margins almost equally the reason to stock Magnum.

Test 8 - Factor analysis ( For retailers )

$\mathrm{KMO}$ and Bartlett's Test

\begin{tabular}{|c|c|c|}
\hline \multicolumn{2}{|c|}{ Kaiser-Meyer-Olkin Measure of Sampling Adequacy. } & .873 \\
\hline \multirow{3}{*}{ Bartlett's Test of Sphericity } & Approx. Chi-Square & 975.610 \\
\hline & Df & 66 \\
\hline & Sig. & .000 \\
\hline
\end{tabular}




\section{Total Variance Explained}

\begin{tabular}{|c|c|c|c|c|c|c|c|c|c|}
\hline \multirow[b]{2}{*}{ Component } & \multicolumn{3}{|c|}{ Initial Eigenvalues } & \multicolumn{3}{|c|}{ Extraction Sums of Squared Loadings } & \multicolumn{3}{|c|}{ Rotation Sums of Squared Loadings } \\
\hline & Total & $\%$ of Variance & Cumulative \% & Total & $\%$ of Variance & Cumulative $\%$ & Total & $\%$ of Variance & $\begin{array}{l}\text { Cumulative } \\
\%\end{array}$ \\
\hline 1 & 5.924 & 49.367 & 49.367 & 5.924 & 49.367 & 49.367 & 4.417 & 36.807 & 36.807 \\
\hline 2 & 2.116 & 17.629 & 66.996 & 2.116 & 17.629 & 66.996 & 2.317 & 19.305 & 56.112 \\
\hline 3 & .833 & 6.946 & 73.942 & .833 & 6.946 & 73.942 & 2.140 & 17.830 & 73.942 \\
\hline 4 & .709 & 5.912 & 79.854 & & & & & & \\
\hline 5 & .553 & 4.608 & 84.463 & & & & & & \\
\hline 6 & .447 & 3.721 & 88.184 & & & & & & \\
\hline 7 & .368 & 3.069 & 91.253 & & & & & & \\
\hline 8 & .283 & 2.358 & 93.611 & & & & & & \\
\hline 9 & .240 & 1.998 & 95.610 & & & & & & \\
\hline 10 & .231 & 1.922 & 97.531 & & & & & & \\
\hline 11 & .172 & 1.436 & 98.968 & & & & & & \\
\hline 12 & .124 & 1.032 & 100.000 & & & & & & \\
\hline
\end{tabular}

Extraction Method: Principal Component Analysis.

Rotated Component Matrix ${ }^{\mathrm{a}}$

\begin{tabular}{|l|l|l|l|l|}
\hline & \multicolumn{3}{l|}{ Component } \\
\cline { 3 - 4 } & 1 & 2 & 3 \\
\hline Q11_Rate_AMUL_CREME_RICH_factors_Durability & .833 & .150 & .047 \\
Q11_Rate_AMUL_CREME_RICH_factors_Consistency & .817 & .415 & -.074 \\
Q11_Rate_AMUL_CREME_RICH_factors_Packaging & .801 & .309 & .109 \\
Q11_Rate_AMUL_CREME_RICH_ffactors_Flavors & .792 & .170 & -.020 \\
Q11_Rate_AMUL_CREME_RICH_factors_Availability & .757 & .458 & .040 \\
Q11_Rate_AMUL_CREME_RICH_factors_Margin & .665 & .179 & .111 \\
Q11_Rate_AMUL_CREME_RICH__along_these_factors_Exclusivity & .649 & .609 & .006 \\
Q11_Rate_AMUL_CREME_RICH_factors_Visibility & .414 & .783 & .034 \\
Q11_Rate_AMUL_CREME_RICH__along_these_factors_Demand & .399 & .782 & .057 \\
Q11_Rate_AMUL_CREME_RICH_factors_Quantity & .059 & .147 & .896 \\
Q11_Rate_AMUL_CREME_RICH__along_these_factors_quality & -.048 & .154 & .875 \\
Q11_Rate_AMUL_CREME_RICH__factors_Pricing & .119 & -.338 & .730 \\
\hline
\end{tabular}

Analysis \& Interpretation - The analysis is done for 30 Retailers

In the above KMO Table, $\mathrm{P}$ Value is 0.000 which means $\mathrm{P}$ Value $<0.05$ This shows that the above parameters are highly significant. Sampling adequacy should be more than 0.5 to perform factor analysis. The above table shows a sampling adequacy of 0.873 which means factor analysis can be performed. The 3 factors that we have extracted from above 12 parameters (items) are able to explain $74 \%$ of variation.

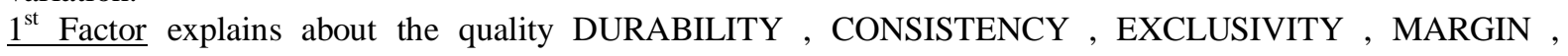
PACKAGING, FLAVORS \& AVAILABILITY provided by Amul

From the table values, we can interpret that factor 1 needs more attention from Amul since there is plenty of room for improvement since retailers have rated most of the parameters in this factor as negative.

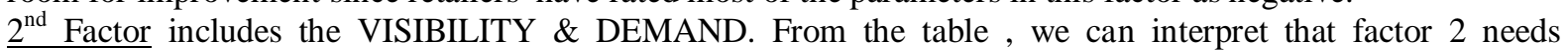
moderate level of attention from Amul as retailers are moderately satisfactory about parameters defining factor 2.

3rd Factor includes QUALITY,QUANTITY\&PRICING . From the table values, we can interpret that retailers are quite satisfied about the parameters making Factor $3 \&$ hence factor 3 needs least part of attention compared to other 2 factors. 


\section{Conclusion}

- Premium ice cream are a product for people living in popular areas as they tend to have premium ice cream more as compared to others.

- Amul's Crème Rich which is a premium ice cream gives good quantity and quality at half the rate of other premium ice creams.

- Amul's being a national brand has its own advantages of better retail penetration than other premium ice cream

- The age of target audience for these premium ice creams is between 21-30. IT means the primary consumer of these premium ice cream are the youths of the nation.

- Taste and Flavors are the key factors for the consumer to purchase these premium ice creams. Hence Amul's Crème Rich can concentrate on developing new flavors and improving the taste.

- This also concludes that HUL's Magnum is the most popular premium ice cream in the market which is currently available than other premium brands.

- The Brand ambassador for Magnum had a significant impact in order to create Magnum's awareness.

- People are willing to spend less than Rs.250 on these premium ice creams.

About Extrusion Bars concept

- Extrusion bar concept is very popular among the Premium Ice cream segment.

- Consumers prefer extrusion bar concept more than other serving types.

- Customers are willing to buy Amul's Crème Rich if it comes in extrusion bars.

- Also most of the retailers are also willing to stock Amul's Crème Rich if it comes in extrusion bars.

- Retailers also agree that there is huge demand for Extrusion bars as customers don't have to carry the packaging \& it's easy to be discarded after consumption.( the stick ).

\section{References}

[1]. Schiffman and Kannuk, Conumer Behaviour ,Publisher : Pearson $4^{\text {th }}$ edition , (1991)

[2]. Chunnawala SSA, Compendium of Brand Management, Himalaya Publishing House Mumbai,(2004).

[3]. Marketing management ,Ramaswamy Namkumari , Himalaya Publishing House

[4]. Robert 1 Steiner, "Does advertising lower consumer price ?’Journal of Marketing 37, no.4 Oct 1990.

[5]. www.amul.com

[6]. www.kwalitywalls.in 